\title{
PALAEO VOLCANIC RELIEF FORMS AS A PART OF THE GEOHERITAGE IN THE REPUBLIC OF MACEDONIA, THEIR VALUATION AND PROTECTION
}

DOI: http://dx.doi.org/10.18509/GBP.2018.06

UDC: 551.4.07(497.7)

\author{
Anita Todorova \\ Dragan Kolchakovski \\ University of "Ss Cyril and Methodius"-Skopje, Faculty of natural sciences and mathematics, \\ Institute of geography, Skopje, Republic of Macedonia
}

\begin{abstract}
In its geological evolution, the territory of the Republic of Macedonia was characterized by a great volcanic activity, but given the fact that active volcanic processes are not present today, the palaeo-volcanic relief forms are being emphasized. They occur in the form of volcanic cones, volcanic necks or plugs, remnants of volcanic craters, plateaus and other forms that are most prominent in the areas of extinct volcanic activity. The significance of the objects of the geoheritage is based on their defined values. Upon the termination of the volcanic activity to date, the volcanic forms are significantly morphologically modified mostly as a result of the large erosive processes and anthropogenic influences. Therefore, the prominent palaeo-volcanic relief forms that are part of the geoheritage need adequate protection. They deserve special attention, due to the fact that some of them are natural rarities that exceed not only the borders of the Balkan Peninsula but also in Europe.
\end{abstract}

Key words: palaeo-volcanic relief forms, geoheritage, protection, valuation

\section{INTRODUCTION}

All occurrences and forms of animate and inanimate nature differ in their variety or diversity. They become the object of observation of several generations of researchers who explore their natural characteristics with a common goal, to have permanent conservation. Geodiversity is defined as the range (or diversity) of geological (bedrock), geomorphological (landform) and soil features, assemblages, systems and processes [20]. The geodiversity of natural phenomena and forms is represented by the geological, geomorphological, pedological, hydrological, climatic diversity and bio-geodiversity. Geological and geomorphological diversity is consisted of various types of rocks, minerals, fossils, relief forms, underground structures and structures of processes that are created during the course of geological evolution [12]. The geomorphological diversity that is like a result from the influence of various endogenous and exogenous forces on the surface of the Earth is reflected in various relief forms. Tectonic movements along with the lithological and structural factors and the influence of the external forces enable the formation of various individual or group relief forms [18]. According to the European Geological Heritage Conservation Association (ProGeo) in 1996, the following geodiversity division was adopted: 
Table 1.Classification of geoheritage sites

A Palaeobiological - macro and micro fauna, flora, vestiges, biochemical, stromatolite

B Geomorphological -regions, caves, volcanoes, waterfalls, fjords, cirques, karst...

C Palaeoecological - former climates, global sediment geology, fossil indicators

D Magmatic, metamorphic and sediment petrological, textured and structural

E Stratigraphical - events, sequences, stratotypes of upper boundaries, interval of stratotypes, biozones of type of sites of broader meaning, palaeomagnetic events...

F Mineralogical

G Structural - main tectonic or gravitational structures

H Economic- of all types, intrusive, discharges, metallic and nonmetallic deposits, mines and quarries

I Others - historical, for development of geological science

Source: [24]

As a part of the geomorphological diversity of particular significance is the palaeovolcanic relief forms, which is distinguished by extremely interesting and representative objects of geoheritage. They occur in the form of volcanic cones, volcanic necks or plugs, remains of volcanic craters, plateaus and other forms that are most prominent in the areas of extinguished volcanic activity. The volcanic relief form can fascinate the general public. Numerous volcanic processes are among those that captivate the human mind at every level and provide fundamental information for understanding how the Earth works [17]. Volcanism has a particularly high interest in the general public due to the humanscale time frame of its actions and the very graphic effects of both destructive and productive aspects [17].

Geodiversity is so diverse that it is difficult to decide which phenomena should be protected and preserved [14]. All geodiversity is impossible to preserve, therefore it is necessary to separate the natural phenomena that possess scientific, educational, cultural and economic values.

\section{VALORIZATION AND THE CONSERVATION OF THE OBJECTS OF GEOHERITAGE}

The process of valorization determines the values of the natural environment, ie whether a natural treasure has the characteristic of natural rarity and whether it possesses the properties for which it should be protected. The valorization of the geoheritage is done in order to determine the values of certain natural rarities and goods given their scientific, educational, cultural, ambiental, recreational, tourist and other significance and the need for their protection and the determination of the conditions for their further use. The valuation of the geoheritage is done based on the natural features and their significance. Every object or phenomenon to be highlighted as an object of geoheritage it should include the following standards: authenticity, representativeness, characteristic, diversity, integrity and landscape value [7].

The purpose of the geodiversity where the values of the natural environment can be emphasized can be determined by applying the following criteria: scientific purpose, educational purpose and recreational purpose [7].

The Australian scientist Gray (2005) pointed out more geodiversity values. They emphasize the intrinsic or existense, cultural, aesthetic, economic, functional and scientific value [6]. The intrinsic values are associated with things exactly what they are intended for, rather than how they can be used by people. Cultural values can arise from 
the beliefs about the formation of some rocks or relief forms. They are related to the origin of rock formations or terrestrial forms. The aesthetic value of geodiversity attracts many tourists who want to see and take advantage of the natural beauties, as well as the opportunities that nature gives them. Geodiversity may also have economic value. It is possible to use coal, oil, gas, treset, uranium and others that are used for raw materials from which energy is produced. It is also important to obtain precious stones, metal minerals, construction material, etc. The functional value represents the possibility of using some parts of nature, including the geosystem services in the sub-rocks that preserve water, oil and gas. The scientific value given by nature is good for carrying out geoscientific research, which gives us a great deal of knowledge about the history of the earth, the processes of shaping its forms, the evolution of life through time, followed by historical research, environmental monitoring where we can follow the paths of climate change, the change in sea level and environmental pollution. It is also of great importance that the above physical evidence be protected for future research and enable the provision of education and training professional geoscientists, students and pupils [6].

After identifying an object from the geoheritage, it is necessary to perform its proper valorization, for which it is necessary to determine its category within similar objects. It is most appropriate to distinguish a large range of objects of geoheritage into five categories: world-rare in the World, European or Euro-Mediterranean rare in Europe and the Mediterranean, regionally rare in part of Europe (Balkan Peninsula or Southeast Europe), national- rare in the state and local-rare in part of the state [9]. The various natural processes and influences of man can negatively affect the objects of the geoheritage, that is, they are degraded or completely destroyed. After their identification as objects of geoheritage, their conservation or protection should be properly carried out. In order to ensure long-term survival, nature protection is imposed as a priority of firstdegree importance. By implementing the geoconservation, significant representative phenomena and processes of geodiversity, such as rocks, landscapes, soil characteristics, etc., are maintained. Geodiversity ought to be conserved for two reasons. First, the geodiversity is valuable and valued in a large number of ways, and second, it is threatened by a wide variety of human activities [6]. Geoconservation includes protection, physical management and improvement of geo-regions of international and national importance for the purpose of scientific and educational exploitation [19]. Conservation refers to the protection and management of natural "goods". Geo-conservation is the preservation of special geological areas (samples) used for scientific research, education and training, where the popularization of Earth's history for the general public is needed in order to improve the conservation practice. The objects of geoheritage can be protected on the very spot of creation in-situ, or separated from it ex-situ [4]. Ex-situ protection is the protection of geological occurrences from their natural original sites, which mainly refers to minerals / rock formations and fossils that are usually placed in the museum or private collections [11]. In-situ protection is the protection of geological occurrences, protection of the place of creation or the place of natural occurrence of minerals / rock formations and fossils [11]. In order to preserve the natural values in the protected areas it is necessary to provide adequate protection regime. The regime for the protection of natural values of protected areas is regulated by law.

Geoheritage is the representative part of geodiversity that may be specifically identified as having conservation significance [14]. The geodiversity and geoheritage phenomena are finite and the principles of sustainable development advise wise use of these resources for the sake of future generations who might also want to use them [13]. 
In this paper presents several palaeo-vulcan relief forms that are worth visiting, and as a result, it is necessary to protect them for sustainable use.

\section{PALAEOVOLCANIC RELIEF FORMS IN THE REPUBLIC OF MACEDONIA}

On the territory of the Republic of Macedonia, besides the presence of various relief forms phenomena, special attention is also given to the palaeo-relief form elements. These are relief forms, whose formation process is long overdue, i.e. exogenous, and in some cases endogenous processes that have contributed to their creation, they no longer work. In the geological past, in different geological fragmentations, intensive volcanic activity with a large quantity of pyroclastic material and various volcanic rocks was taking place on the territory of the Republic of Macedonia. The volcanic activity was particularly intense in the Cenozoic era, in particular in the tertiary and the lower quaternary [22]. Given the fact that the active volcanic processes are not present today, the palaeo-volcanic relief forms stand out. They occur in the form of volcanic cones, volcanic necks or plugs, remnants of volcanic craters, plateaus and other forms that are most prominent in the fields of extinct volcanic activity. The palaeo-volcanic relief forms are objects of geoheritage that are worth to be protected and for to be seen by future generations.

As a result of all that, today, seven areas of the extinct volcanic activity are distinguished on the territory of the Republic of Macedonia. They are: Osogovo-Maleshevska (Deve Bair-Sasko-Delchevsko-Pehchevska), Kratovo-Zletovska, Kumanovo-Sveti Nikole, Shopursko-Damjanska, Kozhuvsko-Vitachevska, Mariovo-Kajmakchalanska and OhridKosel volcanic area [22].

The Osogovo-Maleshevska volcanic area is located in the far eastern part of Macedonia. It has a meridian stretch from the village of Luke to the north via Deve Bair-ToranicaSasa-Delchevo-Pehchevo. The volcanic activity took place during the Paleogene and is represented by several volcanic phases [22]. In the north of the Devebair ridge there are two volcanic phases. The first phase took place in an upper Eocene. The tectonic ridge was filled with seawater where sediments were deposited, and the sedimentation process was accompanied by strong underwater volcanic eruptions. The volcanic activity had a sub-marine character which led to the creation of a volcanogenic-sedimentary series lying through the Paleozoic metamorphics and the Paleozoic granitoids. The second phase took place in the Oligocene and is represented by a large effusion of granodiorite magmaquartz latite [22]. In the central and in the southern part of this volcanic area, the quartz latite, andesite, and volcanic cones are represented. The volcanic cones Bukovik and Belo Brdo are clearly distinguished here. The volcanic cone Bukovik is located $3 \mathrm{~km}$ northeast of Pehchevo. The cone has a diameter of about $3.5 \mathrm{~km}$ and an area of $8 \mathrm{~km}^{2}$. The relative height of the cone is about 600-700 m [23]. It is formed of quartz latites and shows marks traces of lava flows. The mineralization of lead and zinc in the Sasa and Toranica areas [2] is also associated with this volcanic activity.

The Kratovo-Zletovo volcanic area is the largest area (over $1000 \mathrm{~km}^{2}$ ) of the volcanic area in the Republic of Macedonia [1]. It is spatially located in its northeastern part between Kozjak mountain to the north, the river Bregalnica to the south, Ovche Pole to the west, and the Osogovo mountains to the east. The volcanic activity has been occurring in several volcanic phases over tertiary and lower quaternary (Pleistocene), with maximum paroxysms in Miocene and in Pliocene-Pleistocene [22]. The volcanic eruptions had an underwater and continental character and provided a remarkably rich volcanic material that settled alongside the neogenic lake sediments. The volcanic 
material is represented by pyroclastic material (ignimbrits, breccias, sand, ash and dust) and volcanic rocks (quartz porphyry, andesites, dacites, trachyandesitis, trachytes, kyanites, basalt, etc.) [22]. The average power of the ejected pyroclastic material is estimated at $700 \mathrm{~m}$ [1]. This volcanic area is characterized by numerous volcanic cones and calderas, such as: the Lesnovo cone and caldera, the cone of Plavica, a double caldera of Rajchanski Hill, volcanic neck Zdravchi kamen, volcanic cones near Uvo-Bukovec and Orlova Chuka and the caldera near Preslap [15]. The Lesnovo cone and caldera is located near the village of Lesnovo with an area of $12 \mathrm{~km}^{2}$ [16]. The cone has steep sides and rises above the surrounding relief form for $400 \mathrm{~m}$. At the top of the Lesnovo cone a caldera is well preserved with a diameter of $1.5 \mathrm{~km}$ and a depth in the central part of 150$200 \mathrm{~m}$ [15]. Near the center of the caldera, 7-8 volcanic necks are ring-shaped. The Volcanic cone and the caldera Plavica are located between Kratovo and Probishtip. The volcanic cone over the surrounding relief forms rises by 400-500 $\mathrm{m}$ and has a diameter of 3-4 km. Around the main cone, some exaltations are rising concentrically, representing a parasitic cones with a height of 50-150 [23]. The parasitic cones with Plavica make up a complex ring structure. The volcanic cones Uvo-Bukovec are located above the village of Blizanci. They are only $1 \mathrm{~km}$ away from each other and are separated by a shallow saddle. Here, the volcanic activity is represented by the lava flows of dacites. From the parasitic cones the most impressive one is the cone Kunovska Chuka. The entire Paleovolcanic structure, along with the parasitic craters, extends to an area of about $10 \mathrm{~km}^{2}$, and the lava-volcanoclastic material spreads to an area of about $35 \mathrm{~km}^{2}$ [15]. The volcanic neck Zdravchi Kamen is located on the left valley side of the Kratovo River, south of the village Zhivalevo. It is built of andesite rocks that, when flowing through the volcanic canal, received a columnal secretion [23]. The Rajcanska volcanic cone and caldera extends between the villages: Vrbica, Sokolarci, Spanchevo and Rajchani. It covers an area of about $25 \mathrm{~km}^{2}$. They are represented by two calderas that were part of the then volcanic cone. The volcanic activity is represented by volcanic-sedimentary breccias and andesite tuffs [15]. The volcanic bombs in the Kratovo-Zletovo volcanic area are registered on the left valley side of the Kiselica river. The occurrences are noticeable along the road, to its incline, from the right valley side towards Probishtip. The site is located 400-410 $\mathrm{m}$ above sea level and occupies a small area of about 0.5 ha. It is a classical phenomenon of pyroclastic material, i.e. volcanic bombs. There are also volcanic bombs with a diameter of up to $0.8 \mathrm{~m}[10]$.

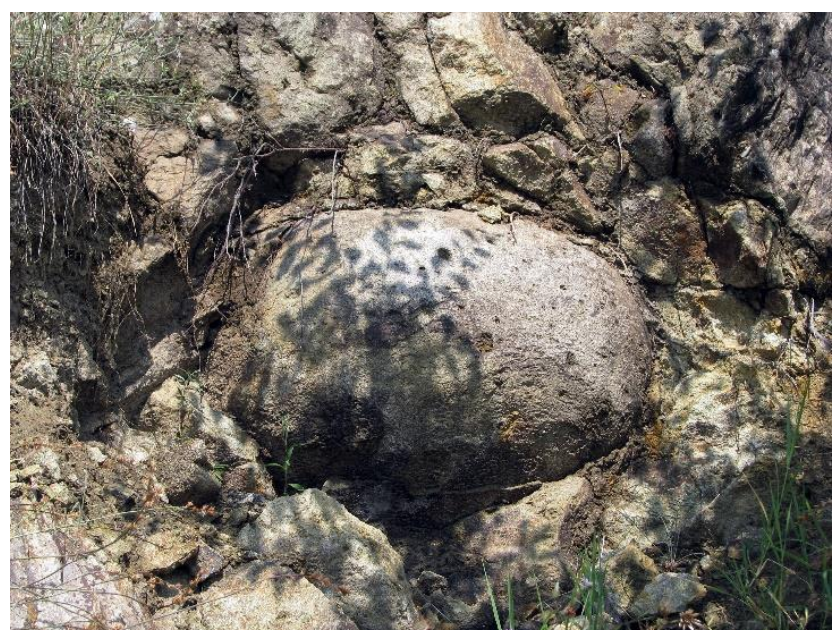

Figure 1. Volcanic bombs near Provishtip Photo: Kolchakovski 
The Kumanovo-Sveti Nikole volcanic area is located between Kumanovo and Sveti Nikole. The volcanic activity is represented by the outflow of basic lava and volcanoclastic material. The lava that was produced on the surface of the earth had built basins and plateaus. With the consolidation of the lava volcanic rocks were formed which are represented by trachybasalts, kyanites, shoshonitic basalts and others. The volcanic eruptions were accompanied by weak explosions and the eruption of volcanoclastic material. The age of this volcanic activity is considered to be from the Pleistocene (Lower Quaternary) [22]. The volcanic necks called Tatichev Kamen is located near the village of Kokino, northeast of Kumanovo, at an altitude of $1013 \mathrm{~m}$. Its age is estimated to be 32-33 million years old and is due to the secretion of pyroxene andesites and andesites [10]. As a consequence of the endogenous factors, the small and andesite mass pours out as a very viscous-dense resinous mass through the inlet channel (which is believed to have been through today's top of Tatich's Kamen) forming a geomorphologic form of a dome that fits the mentioned top and micro-location "thrones". The whole andesite massif with dome shape geomorphological form is dispersed on the magmatic products of secretion with forms of parallelepipedic quads, cubes, short columnar bodies with dimensions from $0.5 \mathrm{~m}$ to about 1-1.5 $\mathrm{m}$. In some places encircled are cubes, quadrants and more. The rounded form was obtained from the influence of exogenous factors. The entire andesite massif from a geomorphological point of view reminds of the shape of a "saddle" or "dwarf camel" because it is composed of two domes of which the highest dome is called Tatichev Kamen, and the smaller dome is the micro-location called "thrones" [5]. The basalt plateaus site is located in the area of the village of Mlado Nagoricane. It is characteristic that they represent a series of eight plateaus (cones) with height from 50 to $80 \mathrm{~m}$ with a meridian stretching path [8]. The Neotectonic movements and erosion influenced the separation of the single plateau. This resulted in the only plateau splitting and forming more small plateaus or cones. The largest of these basalt plateaus is the basalt plateau Cabernik, the smaller of which is Sreden Kamen, and the smallest is the basalt plateau Ostrovitsa [3]. The most prominent basaltic plateaus are "Kostoperska Karpa" and "Vujovska Karpa" which are located directly to the main road Kumanovo-Kriva Palanka. They had a meridian stretching path and, according to J. Cvijic, this object belongs to the system of meridian stretches, which begin from Katlanovska Banja, and all the way to Ruple east of the Grdelichka ravine. The cones are composed of blackish large basalt, and in some of them there are red layers of a very light sponge mass of lava [3].

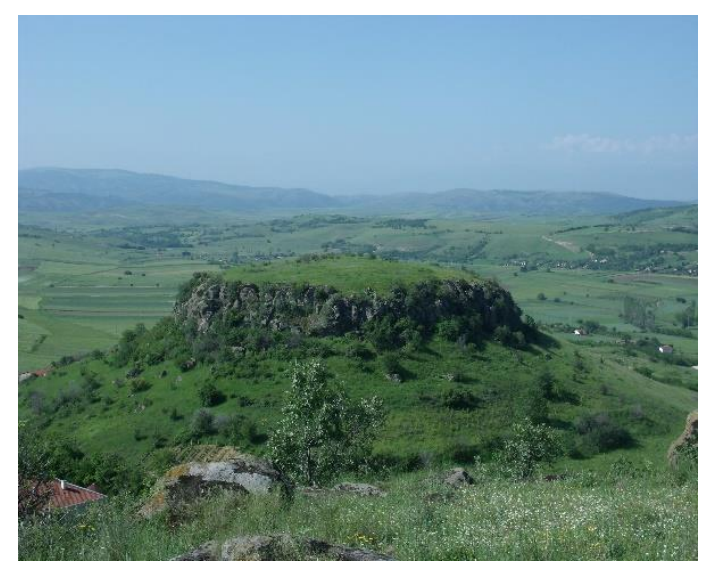

Figure 2. The basalt plateau near Mlado Nagoricane

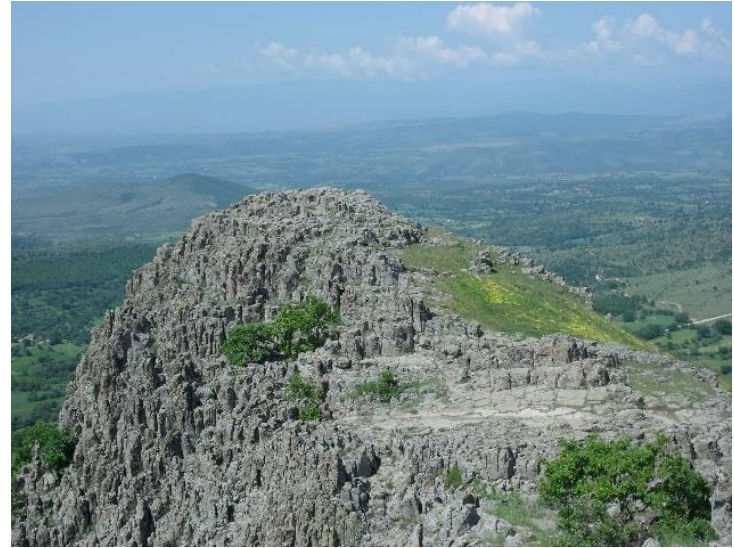

Figure 3. The volcanic necks Tatichev Kamen (the site Kokino)

Photo: Todorova 
The Chopursko-Damjanska volcanic area is spatially located between the villages of Shopur, Damjan, Bucim, Brest and the river Kriva Lakavica. Volcanic activity took place during the Paleogene and is represented by two volcanic phases. The first phase took place at the end of an upper Eocene in which underwater volcanic eruptions took place by spilling large quantities of pyroclastic material. The second phase took place in Oligocene-Neogene. It is represented by volcanic cones of intermediate rocks, andesetes and trachyandesites. The volcanic cones and craters by the name of Pilav Tepe, Orlova Glava, Treskavica Chuka and others, stand out here. For this volcanic activity, the connection with mineralization of the copper in Bucim and Borov Dol and the mineralization of iron in Damjan is connected [22]. The volcanic cone Pilav Tepe is located in the valley of Medenska Reka (right tributary of Lakavica), on the right side of the ravine (Dervenska Ravine) along the Radovis-Stip road. The volcanic cone is 150 meters high and has a conical look. It is the morphologically most shown phenomenon of tertiary, upper eocenic magmatism in the region of Buchum-Damjan. It was formed from upper-Eocene andesites [10]. To the south of the volcanic cone Pilav Tepe at a distance of $1 \mathrm{~km}$ lies the second volcanic cone in the form of a volcanic neck and is called Plocha. The relative height is about $150-200 \mathrm{~m}$.

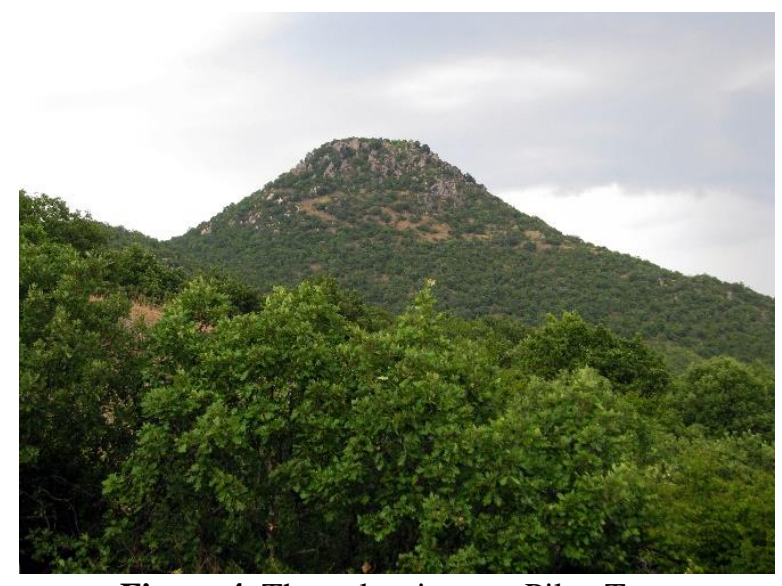

Figure 4. The volcanic cone Pilav Tepe Photo: Kolchakovski

The Kozuf-Vitachevska volcanic area is the youngest volcanic area on the territory of the Republic of Macedonia. This volcanic area is divided into two parts. Its age is defined as Miocene-Pliocene to Quaternary. It is spatially located between Kavadarci in the north and the Kozuf mountain in the south, and continues into Greece as Voras. The volcanic activity was performed in several stages. The first phase is represented by the outflow of an intermediate lava, and from the rocky masses is represented with andesites. The andesites are prevalent in the Majdan (Alshar), mountain Dudica, the valley of Stara Reka, Mircevica, the locality of Sharena and Zharnica. In the region of Dudica, copper mineralization appeared, and in the region of Alshar, the mineralization is represented by antimony, arsenic and thallium. In the second volcanic phase, the strong volcanic eruptions was performed by the outflow of intermediate andesitic lava and the ejection of a large amount of pyroclastic material. From this pyroclastic material is formed the plateau Vitacevo, and from the andesites is formed volcanic cones of Vlasov Grad, Kopriva, Ostrec, Momina Cuka, Prasnik, Cvrstec, Dudica and others were linearly distributed in the east-west direction [22]. The volcanic cone Vasov Grad is located on the western slopes of the Kozuf mountain southeast of the village of Mrezhichko. The 
volcanic cone is of height of around 500-600 $\mathrm{m}$ and it is built of andesitic lava. Around the cone there are several parasitic cones such as: Ostrec $(1550 \mathrm{~m})$, Cvrstec $(1535 \mathrm{~m})$ and others [23].

The Mariovo-Kajmakchalan volcanic area extends between the village of Vitolishte in the north and the mountain Nidze with Kajmakchalan in the south. The volcanic activity took place with a large production of pyroclastic material, which is represented by tuffs, breccias and agglomerates. Volcanic cones also stand out in this area, of which most known are the following: Kamila, Crna Tumba, Kravica and others [2].

The Ohrid-Kosel volcanic area is located north of Ohrid and has a meridian stretch from the village of Pesochnica, Crvena Voda to the north and to the south extends through the villages of Vapila, Kosel to the village of Velgoshti. Here, there is a system of longitudinal fault structures, the most significant of which is the Koselian fault. Along these fault structures in the villages of Pesochani, Vapila, Kosel and Velgoshti, there are also post-volcanic phenomena represented by the outflow of gases of carbon dioxide and sulfur hydrogen. The most marvelous post-volcanic phenomenon is the sulfur spring Duvalo near the village of Kosel [22].

\section{VALUATION AND PROTECTION OF THE PALAEOVOLCANIC RELIEF FORMS}

According to the proposed measures for determining the values of the natural features, the palaeo-volcanic relief forms have their specific characteristics. Because of their primary form of occurrence of volcanic origin, they are characterized by great authenticity. The relief forms have not been modified by people. As a typical example, the volcanic cone Pilav Tepe can serve as it is clearly expressed. These relief forms occupy the largest percentage of the surface of the Republic of Macedonia in the eastern part and are typical in their appearance. The largest and most prominent palaeo-volcanic relief forms is the Kratovo-Zletovo volcanic area. The palaeo-volcanic relief forms occur in various forms of volcanic cone, caldera, volcanic neck and pyroclastic material, i.e. volcanic bombs. Because they are witnesses of the former volcanic activity in these areas, they are distinguished by their attractiveness, that is, representativeness. They represent a whole (integrity) for volcanic activities that took place in the Cenozoic era (tertiary and the lower quaternary) on the territory of the Republic of Macedonia. The overall picture they create has a landscape value, since these palaeo-volcanic relief forms are distinguished by their appeal and they are strikingly appearing on the relief. The Lesnovo cone attracts particular attention and the caldera with the surrounding area. According to the purpose offered by these palaeo-volcanic phenomena, they can be used for scientific research, for analyzing their stance and in what period of time they occur. They can also be used for educational purposes, where it will be presented that there are no active volcanoes on the territory, but that these forms testify to the past activity. The basalt plateaus of Mlado Nagoricane and the volcanic neck Tatichev Kamen, because they have a characteristic way of becoming, can be used for scientific and educational purposes. At the site of the occurrence of the volcanic bombs near Probishtip, a geological profile can be made for educational purposes and to set up an information panel that will serve to get more information about the way these volcanic bombs are formed. The volcanic cones, calderas, volcanic necks and plateaus can also be used for recreational purposes, that is, as a picnic or resting place. On the volcanic cone Plocha due to selective erosion, vertical rocky sections have been formed for alpinism. According to the distinguished values of 
the Australian scientist Gray, the presented palaeo-volcanic relief forms fulfill the intrinsic or existense value, i.e. they are in their original state. Cultural values are represented on the volcanic neck Tatichev Kamen because in the past it was used for astronomical measurements. This relief form shape was most comfortable for performing astronomical observations, since it offers countless well-formed and constant benchmarks for astronomical measurements. The aesthetic value is quite significant, because according to the way of appearance and the prominent relief forms attract visitors who love nature and with the opportunity to benefit from the benefits offered such as rock climbing, hiking, and others. From the economic value it is important to say that these areas are significant, because there is excavation of copper, lead-zinc ore, thallium, arsenic, antimony and other. There are also quarries on certain cones, where the rocks are used for construction material. It is very difficult to thoroughly assess the values of nature. Using the valorization an analysis is being taken of the given criteria whether an object can respond positively to one criterion or more and as a result of that analysis it can be proposed as an object of the geoheritage. According to the prominent values possessed by the palaeo-volcanic relief forms, some of them are not only important from the national level, but also exceed the Balkan and European spaces. The volcanic neck Tatichev Kamen (the site Kokino) is of global importance because it was placed on the tentative list of UNESCO protection in 2009 [25], but not as a natural heritage but as an archaeoastronomical site. The basalt plateaus of Mlado Nagoricane and Lesnovo cones and caldera are also rare occurrence not only in the Republic of Macedonia, but also in the Balkan Peninsula. Other volcanic cones, caldera and volcanic necks are also of great importance for protection and promotion, but the more important are the following: The volcanic cones Pilav Tepe, volcanic cone Vasov Grad, volcanic neck Zdravci Kamen and others. On Lesnovo cones and caldera more detailed studies are already being done of natural values and are adequately presented by placing information panels, road signs, presentations on web pages and flyers. Apart from the effects of the erosive-denudation processes that contribute to the leveling of the primary volcanic relief forms, i.e. destroying the tops of the cones where the crater was located, the greatest threat to them is the anthropogenic influence. As a threat for destruction of the volcanic bombs is the potential expansion of the road. For the volcanic cones a threat of destruction is the opening of quarries, or the exploitation of mineral resources. A typical example is the partial destruction of Lesnovo cones is the alleged mining of stone. In the basalt plates near Mlado Nagoricane during the field research, it was noted that one basalt plateau had wire lines and a substation installed, and a monument was built at the basalt plateau "Zebrnak", and also the basalt was exploited too. For these reasons, the relief forms should be protected on the spot, i.e. to carry out in-situ protection or take samples for museum collections, i.e. to ex-situ protection. Typical for the application of ex-situ is the mineralogical collection of the lead and zinc mine "Zletovo", which is exhibited at the Mineralogical-Ethnological Museum in Probishtip.

Samples of volcanic bombs can also be taken to be displayed in the museum and faculty collections. Typical examples are the Faculty of Natural Sciences and Mathematics and the Natural Science Museum in Skopje. For prominent volcanic cones, calderas, volcanic neck and plateaus and is applied in-situ protection. For their specific protection they need to be protected by legal regulations. Apart from the volcanic neck Tatichev Kamen (the site Kokino), which is placed on the tentative list of UNESCO, also stands out the Lesnovo cone and caldera, which has been declared a monument of nature. It is on the list of geological rarities of the Rare Protection Office in the Republic of Macedonia. It 
is worth mentioning that the basalt plateaus according to the corresponding legal regulations are included in the list of draft laws for proclamation as a monument of nature, and thus will acquire adequate protection from the occurrence of anthropogenic influences. For the remaining palaeo-volcanic relief forms, additional studies are conducted for their research so that they can be properly protected. A great interest in studying, presenting and taking appropriate measures for the protection of the palaeovolcanic relief forms is through the preparation of studies for the protection of natural values at the level of the whole country or for individual areas. Such examples are the study of the geodiversity and the geoheritage in the Republic of Macedonia and other components of nature (biological and landscape diversity), the study on valorization with the proposal for the establishment of the protected area "Osogovski Massiv", the study on the situation for the potentials for development of tourism in the Eastern planning region and others.

\section{CONCLUSION}

Up to 2.5 million years ago, on the territory of the Republic of Macedonia an intense volcanic activity took place. As a result, today as a witness we have the characteristic remnants of volcanoes, solid lava flows, tuffs, volcanic bombs, and more. By determining the values they possess, they deserve to be treated as a part of the geoheritage in the Republic of Macedonia for which a special presentation is needed. They should be properly presented for to be used for scientific and educational purposes, all in order to be protected so they can also serve for the future generations. Through making and setting up informative panels, signposts and presentation via web pages and flyers, the palaeovolcanic relief forms will be affirmed to the point that they can also be the main tourist attraction. It is also worth noting that the volcanic rocks are exposed to some erosive processes, and because of which various denudation relief form shapes appear in the relief forms, such as rock pillars, forms like cups and footprints and other that should awake the interest of the geo-researchers and the public. The current state of the number of protected areas in the Republic of Macedonia is 86 objects or $8.9 \%$ with a total area of 229719.07 ha [21]. The number of protected areas can significantly increase through preparation of various studies for inventory, valorization and protection of the palaeovolcanic relief forms. As a result of that, the Republic of Macedonia is rich with numerous objects of geoheritage including volcanic cones, caldera, volcanic necks and volcanic bombs that have high values and attractiveness and who can adequately be interpreted, arranged and promoted for geotourism purposes.

\section{REFERENCES}

[1] Arsovski M., Tectonics of Macedonia, Faculty of Mining and Geology, Shtip, pp. 1-305, 1997.

[2] Boev B. General Geology, Geomap, Skopje, pp. 1-301, 2006.

[3] Cvijic J. Geography and geology basics of Macedonia and Old Serbia; Belgrade book 1, pp.1688, 1906.

[4] Dangich A. Geological heritage of Serbia-identification, categorization and protection of heritage objects, Journal of the Institute for Nature Protection of Serbia, Belgrade, $n{ }^{\circ} 48-49$, pp. 77-78, 1998. 
[5] Final report on the geological-petrographic-mineralogical-geomorphological characteristics of the micro-location Kokino-Kumanovski, Society for Geological, Engineering Geological, Hydrogeological and Geophysical Research Geologing DOO, Skopje, pp. 1-46, 2009.

[6] Gray, M. Geodiversity and Geoconservation: What, Why and How? George Wright Forum, vol. 22, ${ }^{\circ} 3$, pp. 4-12, 2005.

[7] Hadzi Pecova S., Zikov M., Penev P. Mountain range Jakupica-exploration and valuation of natural heritage, Skopje, pp. 17-25, 1999.

[8] Klincharev S. Anastasovski V. Geological and geomorphological heritage of the Republic of Macedonia, Journal of the Serbian Institute for the Protection of Nature, Belgrade ${ }^{\circ} 48-49$; pp. 91-97, 1998.

[9] Kolchakovski D., Bogdanova B. The geodiversity in the Republic of Macedonia and its significance (identification, classification and protection), Proceedings of the second congress of the geographers of the Republic of Macedonia, Ohrid, pp. 64-68. 2000.

[10] Kolchakovski D. Recent evidenced localities in the Republic of Macedonia in the function of protecting geodiversity, Bulletin of Physical Geography, Skopje, n ${ }^{\circ}$ 7-8, pp.15-27, 2011.

[11] Law on Nature Protection ("Official Gazette of the Republic of Macedonia", no. 67/04, 14/06, 84/07, 35/10, 47/11, 148/11, 59/12); Skopje

[12] Ljeshevuch M.A. Geodiversity as a condition of the environment, Bulletin of the Faculty of Geography, Belgrade, L, pp. 17-32. 2002/2003.

[13] Maran, A. Geoconservation in the Balkan region - Practices and legal instruments. Bulletin of the Natural History Museum in Belgrade, 1: pp. 41-63, 2008.

[14] Maran Stevanovic A. Methodological conclusions for the geoheritage site assessment: a proposal for Serbia, Geological analysis of the Balkan Peninsula, Belgrade, no. 76, pp. 105-113, 2015.

[15] Milevski I., Basic features of the palaeo-volcanic relief form in the western part of the Osogovo massif, Geographical Reviews, Skopje Vol. 40, pp. 47-67, 2005.

[16] Milevski I. Geomorphological characteristics of Kratovo-Zletovo palaeovolcanic area, Proceedings of the XIX CBGA Congress, Thessaloniki, Greece, vol. 99, pp. 475-482, 2010.

[17] Németh K., Casadevall T., Moufti R.M., Marti J., Volcanic Geoheritage; Geoheritage 9; Springer; pp. 251-254, 2017.

[18] Peshevich D. Geodiversity of Banja Luka region and integral concept of nature's protection: Collection of papers, Faculty of Geography at the University of Belgrade, Belgrade, Vol. LVII, pp. 229-242, 2009

[19] ProGEO, Conservation of our shared geo-heritage-a protocol on geoconservation principles, sustainable site use, management, fieldwork, fossil and mineral collecting; Sweden, pp. 1-10, 2011.

[20] Sharples C. Geoconservation in forest management-principles and procedures, Forestry Tasmania, Tasforests Vol. 7, pp. 37-50, 1995.

[21] State Statistical Office; Environmental Statistics, Skopje, pp. 136, 2017.

[22] Stojanovic M. Areas of extinct volcanoes on the territory of SR Macedonia, Annual proceedings of the Institute of Geography, Skopje, $\mathrm{n}^{\circ}$ 30, pp. 149-166, 1986.

[23] Study on geodetic and geoheritage of the Republic of Macedonia and other components of nature (biological and landscape diversity), Ministry of Environment and Physical Planning, Skopje, pp. 1-503, 2016.

[24] Wimbledon W. A. P. National site selection, and stop on the road to a European Geosite list. Geologica Balcanica, Special issue Geological Heritage, BAN, pp. 15-28. 1996.

[25] http://whc.unesco.org/en/tentativelists/5413/ 